\title{
Developing "Compagement" Model for Evaluating Human Resources of the Organization
}

\author{
Irina A. Ivanova ${ }^{1}$ and Galina A. Sazhaeva ${ }^{1^{*}}$ \\ ${ }^{1}$ Bauman Moscow State Technical University, 2nd Baumanskaya str., 5/1, 105005, Moscow, Russia
}

\begin{abstract}
At present one of the main development vectors for the economy of Russian Federation is aimed towards achieving the trajectory of sustainable development [1] which is based on innovation-driven growth of Russian enterprises. Innovation processes and innovation-driven upgrade in particular help enterprises to adapt to constant changes [2]. Because of that innovation potential of enterprises becomes more and more important. This potential is used for achieving high level of the organization's activity and includes labor, material, financial, information, and other resources. The most significant of the specified resources is labor or human resources, because this particular «resource» creates and regulates flows of other resources. The basis of innovation potential of the organization's human resources is formed by abilities, competences, and skills of employees, necessary for achieving the stated objectives and efficiently fulfilling the assigned tasks which, in turn, lead to successful development of the enterprise. This study presents development of organizational decisions in the area of human resource management in the form of «compagement» model development for future use in the evaluation process of the organization's human resources. This work is aimed at enhancing the human resource management system's efficiency thanks to increased effectiveness of selection and employment, motivation of human resources, training, substitution planning, and forming of the employee pool, evaluation and assessment of employees.
\end{abstract}

\section{Introduction}

Successful development of the modern enterprise, in the first place, is based on skilled personnel, innovative potential of human resources, abilities, competences, and skills of the employees. That is why methods of selection, evaluation, and development of the enterprise's human resources potential, and its constant growth towards empowerment of creative abilities become especially important [28]. The aim of this study is development of methodology (recommendations) of enhancing human resources management in the modern organization based on creating and developing relevant methods for personnel evaluation. Analysis of personnel competence and engagement levels forms the foundation

\footnotetext{
*Corresponding author: sazhaeva.g@bmstu.ru
} 
of these methods. The study determines main mechanisms for evaluation of human resources, analyzes main approaches to the notions of «competency-based approach» and «employee engagement», and describes qualitatively new model of human resources assessment - «Compagement».

\section{Competence and engagement}

There are two approaches to defining of the term «competence»: American and European [5]. Adherents of the American approach explain competence as employee features, necessary for his or her correct behavior, and followers of the European approach - as the ability of an employee to act according to the rules of the organization. In other words, the American approach is concentrated on behavior standards and defining the employees' duties for achieving the most effective results, and the European one - on setting the minimal level which must be achieved by an employee for the same purpose. By combining these two approaches we define the competence as a certain characteristic of an employee that is necessary for achieving the highest performance indicator and which can be assessed and/or measured.

Competences are the necessary condition of competence, i.e. a person can be competent in a certain area only of he or she has all competences, necessary for that. Competence is the ability of a person to solve work tasks effectively and achieve high goals. The term was first used by R. White in his work «Motivation reconsidered: the concept of competence» [15] to describe personality characteristics, immediately connected with high quality of performing work, based on dedicated training and motivation for carrying out of professional duties. CIPD's paper «Competence and competency frameworks» defines competence as a system of standards or the minimal set of requirements, necessary for effective work efforts [16].

The higher the match between the employee's competences and professional requirements, the stronger his or her motivation for achievement and satisfaction, and better the quality of his or her work. This match is exposed by evaluating individual characteristics of a potential employee, conformity to their competency model used in the organization for this job, and the actual model.

The second important area of human resource management in the organization is engagement of its employees. Publications on management look on engagement as a personal characteristic of the employee or his or her psychological state which bring about determination, effort, and drive towards quality fulfillment of professional duties [17].

Frank F.D., Finnegan R.F, Taylor C.F in their work «The Race for Talent: Retaining and Engaging Workers in the 21st century» determine engagement as an amount of arbitrary effort contributed by employees to their work [18]. Indeed, engagement is identified as physical, emotional, and intellectual state that stimulates an employee not only to carry out their direct professional duties proficiently but also step over the bounds bringing as many benefits as possible for the organization. The engaged employee will make emotional choice in favor of organization and undertake maximum efforts towards achieving goals of the organization; the unengaged one will choose his or her personal comfort and interests. An organization with large number of unengaged employees is doomed to failure, so the level of engagement is directly connected to many businessindicators such as profit (engagement growth of 5\% leads to $0,5 \%$ profit growth [22]), market share, customer retention, productivity, employee turnover, and so on. That is why it is necessary to periodically evaluate the engagement level in the company. Personnel engagement indicators are proactivity, passion, desire for active participation in the life of the collective, plan development, and decision taking [23]. 
Engagement can be divided into three components (Fig. 1). First of all, it is satisfaction, i.e. evaluation of key characteristics of work in a company: complexity level of the problems solved, interaction processes inside the organization, motivation, onboarding, and mentoring systems, corporate culture, etc. Secondly, loyalty is the organization's value for the employee, desire to help it thrive and develop. Loyal employees are proud of their workplace, speak positively about the organization, and recommend it to their acquaintances. The third component is proactivity. Proactive employees are prepared to move beyond their job duties and apply considerable effort to achieve the goals of the company.

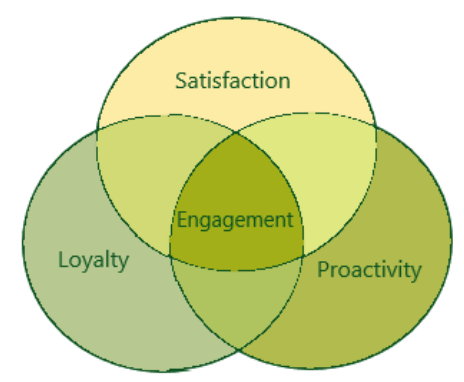

Fig. 1. Engagement components.

Engagement should not be viewed as a one-sided process. Engagement is a mutual process: not only the personnel get involved in the company's activity but the company also goes deeply into interests and goals of its people, gives them the opportunity to take individual decision and act proactively. It looks attentively at their ideas and suggestions, trusts its employees, and provides them with all necessary resources to realize their potential in full. The most widely used approaches to engagement evaluation are three indicators Hewitt Associates («Say», «Stay», «Strive») [32], indicators Towers Watson («Think», «Feel», «Act») [33], Gallup Inc. questionnaire with 12 questions [34].

Studies of different branches of economy in the last decade show low percentage of engagement of employees across the globe [26]. As an example we can look at Gallup organization report [27] which points out that the average engagement of employees across the entire world is only $13 \%$.

\section{Methods}

Testing methods which are more often used for competency evaluation include proactive (open; testees need to describe behavior himself) and/or reactive (multiple-choice) tests; biographical data; interview aimed at discovering a candidate's competencies; modeling of different situations (individual and/or collective). They allow discovering a small group of potential employees among many candidates.

Besides the above methods of evaluation companies often use the method of weighted absolute difference and the method of profile comparison. The first method is based in searching for the gap between requirements to competencies in an organization and competencies possessed by a candidate. Deviation in any direction is considered unfavorable. The calculation is carried out by determining the difference between the required and the candidate's existing competencies. The result is multiplied by the weight, set by the organization according to importance. Then the results are summed up. The best candidate has the least total difference across all competencies. Unlike the method of weighted absolute difference, the method of profile comparison deals with the notion of 
relative importance of personal competencies to the required ones. In this case the best candidate has competencies most closely tied with the required ones.

Empirical research method is used to evaluate the level of engagement of employees. It is based on answers given by a certain group of people to questions related to the study. The survey can be carried out in the form of questioning or interviewing. Questioning means using questionnaires to get answers from the respondents. Questionnaires are forms containing a certain set of questions. Advantages of this method are quick data acquisition, readiness for further statistical analysis, ability to get large quantities of data in a short period of time. Interviewing means collecting information through direct verbal contact with a respondent.

\section{Managing competency and engagement}

Social-psychological state of the personnel is determined by three components: meaningfulness, safety, and availability [39]. Hence, engagement into a given process depends on answers given by employees to the following questions: «What I will get from the participation in this process?», «Is it safe for me?», and «Do I have a possibility to act?». Consequently, to increase the efficiency of labor activity, it is necessary to provide psychologically comfortable environment for employees [40], make them understand that the company believes in success of their work and will support them throughout the work process. Employees' readiness to acquire new experiences and act proactively should be supported by awareness that they have a right for mistake. A mistake will bring about discussion but not sanctions [41].

Effective competence and engagement management allows companies to solve problems most quickly and thoroughly, achieving the desired goal. Engagement level depends on emotional and physical conditions of employees [38], work environment, level of support for initiatives, and many other factors. For this reason it is necessary to build effective feedback which allows managers to learn about preferences, aspirations, and general condition of employees in a timely fashion, quickly react to changes and avert imminent conflicts. Also, the personnel should be able to get all the necessary information about any changes in the organization in a timely manner.

\section{Development of «Compagement» model}

«Compagement» model was developed with the aim of increasing work efficiency and satisfaction of employees. The model will be used for selection and hiring, employee motivation, training, planning of replacements and forming of candidates pool, assessment and appraisal of employees.

«Compagement» model is a 4 x 5 matrix, where rows reflect the level of employees' engagement and columns - the level of their competence. To get the corresponding values, the level of employees' engagement is assessed by questioning and/or interviewing, and also their level of competency according to the appropriate model. The competency model is developed separately for every job title or group of job titles, taking into account particular features of the organization studied. To work effectively, the competency model should be concise, clear, and easy to comprehend. So the language used for describing it should be understandable to all employees, and the elements of the model should be consistent. The model has inherent flexibility. The development needs to take into account complexity and fluidity of external environment, influence of scientific and technological achievements. The model must be fair, i.e. ethnic/gender/age and other differences should by no means influence the established standards. 
There are many «ready» competency models. However, it is often difficult or impossible to apply them, because every organization is unique. In fact, the competency model consists of a set of particular competencies for the particular job title and the scale for assessment of the level of command over every single competency by an employee (from «substantially lower than required» to «higher than required»).

Every employee's assessment results for each particular model are written into a table (an example is presented on Fig. 2). After that the average competence grade is calculated. The result obtained will be used for further employee assessment according to «Compagement» model.

\begin{tabular}{|c|l|c|}
\hline № item & \multicolumn{1}{|c|}{ Rated competence } & Grade \\
\hline 1. & Analytical thinking & 4 \\
\hline 2. & Responsibility & 5 \\
\hline 3. & Decision taking & 5 \\
\hline 4. & Aspiration for development & 4 \\
\hline 5. & Attitude to new tasks & 4 \\
\hline 6. & Self-confidence & 5 \\
\hline 7. & Focus on achievement & 4 \\
\hline 8. & Self control & 5 \\
\hline 9. & Team communication and work & 5 \\
\hline 10. & Developing of engineering decisions & 5 \\
\hline 11. & Team management and collaboration & 4 \\
\hline 12. & Impact and exerting influence & 4 \\
\hline \multicolumn{2}{r}{ Average level of competence } & 4,5 \\
\hline
\end{tabular}

Fig. 2. Competence level of an employee found as a result of assessment according to «Compagement» model.

Dynamic external environment present ever growing number of requirements to employees' level of competence. For this reason the model must be flexible and undergo constant corrections. It is helpful to extend the correction process on employees to whom the model applies.

Now let's assess level of personnel engagement. For this purpose we form 4 groups of employees in accordance with the level of engagement:

1. Highly engaged. Such employees identify themselves with the organization, actively participate in its everyday activities, apply additional effort to achieve the company's aims. They perceive opportunities and threats for the company and are prepared to fight the threats. Work with passion.

2. Moderately engaged. Demonstrate positive attitude towards their company. Intend to work for the company in the long term. Speak positively about the organization. They are prepared to apply maximum effort to help the organization to achieve its aims.

3. Passive. Do not try to participate in everyday activities of the company. They are not motivated to carry out their job duties most effectively. Sometimes can share their thoughts on ways to improve business results but usually prefer not to meddle in affairs of the organization. Critical attitude to changes.

4. Actively unengaged. Do not attract attention, do not participate in everyday life of their organization. Not motivated to perform job duties according to the highest quality standards. Negatively influence their colleagues, «infecting» them with pessimism and lack of confidence in achieving the stated goals.

Employees can be assigned to groups using questionnaires and/or surveys. However, there is a problem of anonymity: nobody will criticize the company knowing that the results of the survey will be presented to a senior manager. There are two solutions to this situation: individual questionnaires and general picture. The first one is possible in organizations with high level trust between employees and managers, and adequate 
response of senior executives to criticism. However, the number of such companies are very small, and anonymous surveys are used more often. This gives the picture for a group of employees / department / organization as a whole but doesn't show the level of engagement of any individual employee which makes it difficult to take correct managerial decisions concerning the employees.

\begin{tabular}{|c|l|c|c|c|c|c|c|}
\hline № & \multicolumn{1}{|c|}{ Assertion } & $\begin{array}{l}\text { Strongly } \\
\text { disagree }\end{array}$ & Disagree & $\begin{array}{c}\text { Somewhat } \\
\text { disagree }\end{array}$ & $\begin{array}{c}\text { Somewhat } \\
\text { agree }\end{array}$ & Agree & $\begin{array}{c}\text { Strongly } \\
\text { agree }\end{array}$ \\
\hline 1 & $\begin{array}{l}\text { I am satisfied with my } \\
\text { work in this organization. }\end{array}$ & 1 & 2 & $(3$ & $(4)$ & 5 & 6 \\
\hline 2 & $\begin{array}{l}\text { I do not want to leave the } \\
\text { organization and work in } \\
\text { another place. }\end{array}$ & 1 & 2 & 3 & 4 & 5 & 6 \\
\hline 3 & $\begin{array}{l}\text { I would recommend our } \\
\text { organizaton to a friend } \\
\text { seekin a job. }\end{array}$ & 1 & 2 & 3 & $(4)$ & 5 & 6 \\
\hline 4 & $\begin{array}{l}\text { My colleagues respect } \\
\text { my opinion and my } \\
\text { feelings. }\end{array}$ & 1 & 2 & 3 & 4 & 5 & 6 \\
\hline
\end{tabular}

Fig. 3. Survey results evaluation.

Methods of survey results evaluation have a peculiarity (Fig. 3): «Strongly disagree» and «Disagree» grades are treated as equal. The same applies to «Agree» and «Strongly agreed» grades. This way we reduce influence of psychological and emotional factors on objectivity of the answers. For example, a person really conscious of a problem within the organization, but filling a questionnaire after an unpleasant conversation with his or her boss, quarrel with a colleague, or being in a bad mood will give the lowest grade though would answer «Disagree» in other circumstances.

\begin{tabular}{|c|c|c|c|c|c|c|c|}
\hline № & Assertion & $\begin{array}{l}\text { Strongly } \\
\text { disagree }\end{array}$ & Disagree & \begin{tabular}{|l}
$\begin{array}{l}\text { Somewhat } \\
\text { disagree }\end{array}$ \\
\end{tabular} & \begin{tabular}{|l}
$\begin{array}{l}\text { Somewhat } \\
\text { agree }\end{array}$ \\
\end{tabular} & Agree & \begin{tabular}{|l} 
Strongly \\
agree
\end{tabular} \\
\hline 1 & $\begin{array}{l}\text { I am satisfied with my } \\
\text { work in this } \\
\text { organization. }\end{array}$ & (1) & (2) & (3) & (4) & (5) & (6) \\
\hline 2 & $\begin{array}{l}\text { I do not want to leave } \\
\text { the organization and } \\
\text { work in another place. }\end{array}$ & (1) & (2) & (3) & (4) & (5) & (6) \\
\hline 3 & $\begin{array}{l}\text { I would recommend } \\
\text { our organizaton to a } \\
\text { friend seekin a job. }\end{array}$ & (1) & (2) & (3) & (4) & (5) & (6) \\
\hline 4 & $\begin{array}{l}\text { My colleagues respect } \\
\text { my opinion and my } \\
\text { feelings. }\end{array}$ & (1) & (2) & (3) & (4) & (5) & (6) \\
\hline & & \multicolumn{2}{|c|}{1} & 2 & 3 & \multicolumn{2}{|c|}{4} \\
\hline
\end{tabular}

Fig. 4. Values for questionnaire grades.

Let us assign new values to grades (Fig. 4): to grades " Strongly disagree» and «Disagree» - 1 point; «Somewhat disagree» - 2 points; «Somewhat agree» -3 points; «Agree» and «Strongly agree» -4 points. Then sum up the resulting points and find the average value. This value reflects the level of engagement of a given employee (individual survey) ot the general picture for a group / department / organization (anonymous survey).

After assessing levels of competence and engagement we come to the «Compagement» model (Fig. 5). 


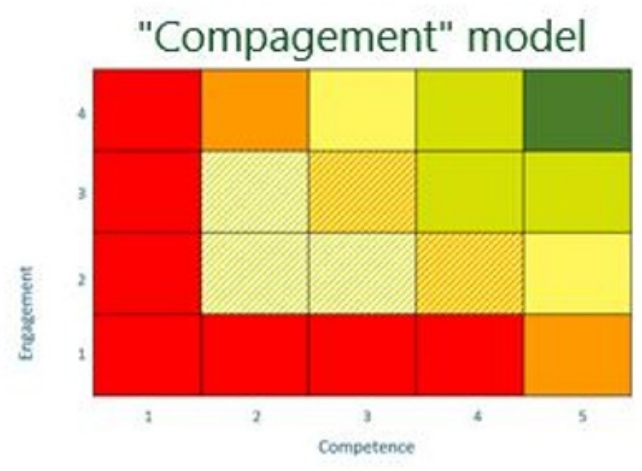

Fig. 5. «Compagement» model.

Let us recall that «Compagement» model is a $4 \times 5$ matrix, where rows reflect the level of employees' engagement and columns - the level of their competence. Each employee of the organization can be positioned into one of 20 matrix cells depending on previously determined values of the average competence grade of an employee and his or her engagement grade. All matrix cells are divided into 6 groups which are visualized in 6 colors for convenience. Names and brief characteristics of groups are presented in Fig. 6.

\begin{tabular}{|c|c|c|c|c|}
\hline № item & Group name & $\begin{array}{c}\text { Group } \\
\text { name in } \\
\text { English }\end{array}$ & Color & Cells $(x, y)$ \\
\hline 1 & "Сорняк" & "Weed" & & $\begin{array}{c}(1 ; 1),(1 ; 2),(1 ; 3) \\
(1 ; 4),(2 ; 1),(3 ; 1) \\
(4 ; 1)\end{array}$ \\
\hline 2 & "Горький лук" & $\begin{array}{l}\text { "Bilter } \\
\text { onion" }\end{array}$ & & $(2 ; 4),(5 ; 1)+(3 ; 3),(4,2)$ \\
\hline 3 & $\begin{array}{l}\text { "Растущая } \\
\text { морковь" }\end{array}$ & $\begin{array}{l}\text { "Growing } \\
\text { carrot" }\end{array}$ & & $(3 ; 4),(5 ; 2)+(3 ; 3),(4 ; 2)$ \\
\hline 4 & "Зелёный огурец" & $\begin{array}{c}\text { "Green } \\
\text { cucumber" }\end{array}$ & & $(4 ; 4),(4 ; 3),(5 ; 3)$ \\
\hline 5 & "Спелое яблоко" & $\begin{array}{l}\text { "Ripe } \\
\text { apple" }\end{array}$ & & $(5 ; 4)$ \\
\hline 6 & "Росток" & "Sprout" & & $(2 ; 2),(2 ; 3),(3 ; 2)$ \\
\hline
\end{tabular}

Fig. 6. Levels of competence possessed.

Let us describe characteristics of the groups mentioned above, and strategies for influencing each of them in more detail. "Weeds» damage the company destroying it from within. Employees with results in cells $(1 ; 1),(2 ; 1),(3,1),(4,1)$ sabotage the company achieving its aims, reduce its appeal both to the employees and existing and potential partners, negatively influence the working atmosphere in the team. Cells $(1 ; 2),(1 ; 3),(1 ; 4)$ have competence level 1 which corresponds to the grade «substantially lower than required». Work of employees not possessing the necessary competencies significantly damages the organization. Consequences of mistakes made by incompetent employees may be evident not immediately but on later stages of producing products. This may increase operational expenses, execution time, and loss of profits. «Weeds» are not prepared and do 
not want to deliver benefits to the company. For this reason it is necessary to get rid of these employees.

«Bitter onion» group consists of people who failed to find their place in the company. This group contains people with unrealistic expectations (cells $(4 ; 2),(5,1))$ or those who are ready to work but do not possess high enough level of competence, or reveal it with caution and only in familiar situations $((2 ; 4),(3 ; 3))$. Such employees usually perform low priority tasks, do not see support from management and loose motivation. Quite often they leave for different workplace. For such employees it is important to understand that they are not cogs in a large machine and the management cares about their development and training inside the company. Coaching system, personal development training, increased responsibility and inclusion into really significant for the organization processes help not only keep the employees in the company but also increase their engagement in the process.

«Growing carrot» performs its job but without passion. It is connected either with satisfactory but yet not high enough level of competence (cells $(3 ; 3)$ and $(3 ; 4)$ ), or with passive attitude of the employee towards business-processes in the company (cells $(4 ; 2)$ and $(5 ; 2))$. By improving work space of the «growing carrot» and providing him or her with opportunities for proactive initiatives, it is possible to increase levels of competence and engagement of this group in quite short time. This, in turn positively influences productivity and overall climate inside the team.

It is necessary to note that employees with assessment results in cells $(3 ; 3)$ and $(4 ; 2)$ can belong both to «growing carrot» group and «bitter onion» group. To determine a group of such respondents, it is necessary to talk with them about the organization: the «bitter onion» will be harsher in his or her assessment and the assessment itself will be mostly negative. In practice, by mentally dividing these cells in half at the level of engagement 2.5 , we will have in the bottom half people who are more likely to belong to «bitter onion» group. People above 2.5 level mostly go into «growing carrot» group.

«Green cucumbers» (cells $(4 ; 4),(4 ; 3),(5 ; 3))$ work in organization with interest and passion, and inspire «sprouts» and «growing carrots». They have desire and capabilities to apply their competences in actual practice, show positive attitudes to the organization, know well its strategic goals, and plan to work for it for a long time.

«Ripe apple» group with the corresponding cell $(5 ; 4)$ in the matrix contains small number of people who identify themselves with the organization and apply all possible efforts and resources to achieve its goals. Performance of such employees may exceed their remuneration level by several times. «Ripe apples» often behave proactively, well capable of analyzing the organization's situation, and see ways of its further development. Most often such employees hold executive positions or occupy them at the first opportunity. An engaged executive inspires his or her employees, and their work efficiency goes up. It may seem that the more people in this group, the better. However, this assumption is not entirely true. Large number of people in «ripe apple» group can lead to increased number of conflicts inside the organization. Also, large number of employees with results in the cell $(5 ; 4)$ can point at adulteration of answers by respondents for whatever reason, as described in clause 1.7 of this study.

«Sprouts» group, occupying cells $(2 ; 2),(2 ; 3),(3 ; 2)$, are new employees of the organization and interns. White and green hatching represents, on one side, uncertainty of such employees, and on another side, potentially high level of engagement, presence of required level of competence, and desire for further development. According to competence approach to selection and hiring of personnel, all candidates not meeting requirements of the organization are eliminated on the first stages of selection. Employees can be in this group for up to a year. If an employee still in «sprouts» group after this period he is transferred to «bitter onion» group. 


\section{Results}

The model allows monitoring dynamics of movement of employees between groups and detecting seemingly insignificant problems. However, these problems heavily decrease employee engagement and prevent them from applying their competences to perform their jobs with maximum effectiveness. Concerning the specifics of applying this model, it is necessary to note that may work on both small enterprises and large organizations in different economic sectors.

«Compagement» model also creates possibility to avoid one-sided and unjust assessment of the work; attract employees to voluntarily determining aims and assessing results of activities and work efficiency; increase influence of assessment on practical activities (assessment has practical, not theoretical application); concentrate employee attention on strategic aims of the organization.

\section{Discussion}

In modern information economy speed of technological and technical changes constantly increases and global competition gets tougher. In this situation highly professional workers possessing large volumes of knowledge and skills are becoming more and more valuable.

Application of different competence models to managing human resources is effective and important in modern economy. Competence models are successfully used in foreign companies, among them French food company Danone, American food company The Coca-Cola Company, Swiss company, the largest in the world food manufacturer Nestlé Société Anonyme, American holding company Johnson\&Johnson, and others. Among Russian-based companies it is possible to point out global energy corporation Public Joint Stock Company «Gazprom», Russian oil and gas Public Joint Stock Company «Rosneft», Russian steelmaking and mining Public Joint Stock Company «Severstal».

At the same time there is growing number of companies conducting studies of engagement of their own employees. It shows the increased interest to this problem. «Compagement» model will allow analyzing levels of competence and engagement, and determine problems hindering performance of employees in a particular job. Engaged employees with the necessary set of constantly improving competences are prerequisite for correct, accurate, and timely execution of assigned tasks. Such employees will be better motivated to work for the benefit of the organization. Experienced, competent experts will be interested in practical application of results of their activities, and new personnel will want to develop their skills and adopt the experience of workers of «older generation».

\section{Conclusion}

The bottom line from everything described above is that «Compagement» model allows to increase motivation towards achievement and training, stimulate proactive behavior, enhance self-confidence and belief in one's abilities. This will improve attitude towards work and perseverance in achieving the highest performance indicators, stimulate employees towards development and acquiring competences including interpersonal ones (for effective interactions with people with different cultures and traditions), and match people with jobs in the most optimal way through using competence models. 


\section{References}

1. O.V. Kozhevina, N.V. Salienko, Methodological aspects of the transition to sustainable industrial development, Science and technology project management. (Metodologicheskiye aspekty perekhoda k ustoychivomu razvitiyu promyshlennykh predpriyatiy, Upravleniye nauchno-tekhnicheskimi proyektami), Proceedings of the Third International Scientific and Technical Conference, pp. 198-202 (2019)

2. M.Z. Karaya, I.A. Ivanova, Innovation as a management tool in a modern company, Full lifecycle management systems for high-tech products in mechanical engineering: new sources of growth (Innovatsii kak instrumentariy upravlencheskoy deyatel'nosti v sovremennoy kompanii, Sistemy upravleniya polnym zhiznennym tsiklom vysokotekhnologichnoy produktsii $\mathrm{v}$ mashinostroyenii: novyye istochniki rosta), Proceedings of the All-Russian Scientific and Practical Conference II, pp. 82-85 (2019)

3. W.B. Schaufeli \& A.B. Bakker, Job demands, job resources, and their relationship with burnout and engagement: A multi-sample study, Journal of Organizational Behavior, 25(3), pp. 293-315 (2004). doi:10.1002/job.248

4. R.W. White, Motivation reconsidered: the concept of competence, Psychological Review, No. 66. p. 333 (1959)

5. Competence and competency frameworks: factsheet, ed. J.Egan (Revised May 2011), Chartered Institute for Personnel and Development (CIPD), 151 The Broadway, London SW19 1JQ, UK. http://www.cipd.co.uk/hrresources/factsheets/competencecompetency-frameworks.aspx (Access date 21.12.2019).

6. W.H. Macey \& B. Schneider, The meaning of employee engagement, Industrial and Organizational Psychology, 1(1), pp. 3-30 (2008). doi:10.1111/j.17549434.2007.0002.x

7. F.D. Frank, R.P. Finnegan and C.R. Taylor, The race for talent: retaining and engaging workers in the 21st century, Human Resource Planning, Vol. 27, No. 3, pp12-25.

8. C. Birzea, Education for democratic citizenship: a lifelong learning perspective, Council of Europe.DGEV/EDU2000/CIT 21:Strasbourg Cedcx:CoE, p.88 (200)

9. Onuchin Andrey, Rozin Mark, Sirotkina (Samoilova) Irina, To work like a holiday (Na rabotu kak na prazdnik), Farmpersonal (2015)

10. Personnel engagement: assessment methods and ways to increase (Vovlechennost personala: metody otsenki i sposoby povysheniya), Business courses with a focus on practice and results available at: https://practicumgroup.com/blogs/stati/vovlechennostpersonala/ (access date: 24.11.2018)

11. S. Crabtree, Global productivity hinges on human capital development, Gallup Blog (2018). Retrieved from http://news.gallup.com/opinion/gallup/ 225752/globalproductivity-hinges-human-capital-development.aspx?g_ source=BLOG_TGB\&g_medium $\% 20=$ topic\&g_campaign=tiles.

12. A. Mann \& J. Harter, The worldwide employee engagement crisis (2016). Retrieved from http:// news.gallup.com/businessjournal/188033/worldwide-employeeengagement-crisis.aspx

13. O.N. Melnikov, D.A. Esipenko, Formation of an organization's innovation activity management environment (Formirovaniye sredy upravleniya innovatsionnoy aktivnostyu organizatsii), Russian Journal Of Innovation Economics, Vol. 9, No. 3, pp. 1077-1090 (2019). doi: 10.18334/vinec.9.3.40953 
14. R.M. Gevorgian, L.M. Martynov, Development trends of modern enterprise management technologies and assessment of their effectiveness in modern conditions (Tendentsii razvitiya sovremennykh tekhnologiy menedzhmenta predpriyatiya i otsenka ikh effektivnosti v sovremennykh usloviyakh), Bulletin of the Buryat State University, Economics and Management, No. 3, pp. 26-34 (2019)

15. Aon Hewitt, Global Employee Engagement Database (2015). URL: http://www.aon.com/attachments/human-capital-consulting

12015_TrendsInGlobalEngagement_Final_v11.pdf (Access date 18.03.2019).

16. Towers Watson, CIPD Employee Engagement Conference (2011) [Electronic resource]. URL: https://www.towerswatson.com/en/Insights/IC-Types/SurveyResearch-Results (Access date 26.12.2019).

17. Gallup Organization. State of the global work place: Employee engagements insights for business leaders worldwide [Electronic resource]. URL: Www.gallup.com/file/strategicconsulting/164735/State\%20of\%20the\%20Global\%20W orkplace\%20Report\%202013.Pdf (Access date 28.12.2019).).

18. G.M. Alarcon, J.B. Lyons, The relationship of engagement and job satisfaction in working samples, Journal of Psychology: Interdisciplinary and Applied, Vol. 145, pp. $463-480$ (2011)

19. Kahn, W.A. Psychological conditions of personal engagement and disengagement at work // Academy of Management Journal, Vol 33, pp 692-724.

20. B.E. Ashforth \& R.H. Humphrey, Emotion in the workplace: A reappraisal, Human Relations, Vol. 48, pp. 97-125 (1995)

21. A. Edmondson, Psychological safety and learning behaviour in work teams, Administrative Science Quarterly, 44, pp. 350-38 